\title{
Bladder Carcinoma
}

National Cancer Institute

\section{Source}

National Cancer Institute. Bladder Carcinoma. NCI Thesaurus. Code C4912.

A carcinoma arising from the bladder epithelium. Approximately $90 \%$ of the bladder carcinomas are transitional cell carcinomas. The remainder are squamous cell carcinomas, adenocarcinomas and small cell neuroendocrine carcinomas. 